\title{
APPROACH AND DESIGN: A METHOD ANALYSIS OF EFL READING COMPREHENSION INSTRUCTION
}

\author{
Harison Mohd. Sidek ${ }^{1 \star}$, Hasimah Ja'afar ${ }^{2}$ \\ ${ }^{1}$ Associate Prof., Universiti Sains Islam Malaysia, MALAYSIA, harison@usim.edu.my \\ ${ }^{2}$ Dr., Universiti Perguruan Sultan Idris, MALAYSIA, hasimah@fbk.upsi.edu.my \\ ${ }^{*}$ Corresponding author
}

\begin{abstract}
There is an ongoing phenomenon among non-English speaking students, particularly at the university level who struggle with reading in English in content areas. One way to alleviate reading problems in English language among non-native speaking students is by ensuring that the English language reading curriculum is coherent at all levels. The purpose of the present study was to explore the type of (EFL) reading comprehension instruction reflected in the Malaysian English language reading curriculum at the levels of Approach and Design, and its alignment with the communicative label. The data for the study were collected from two main curriculum documents, which were the Form Five English Language Curriculum Specifications document and the Form Five English language textbook. A document review was conducted in order to obtain the data, which were in the form of reading tasks elicited from the selected curriculum documents. Manifest content analysis was used to analyze the data. The findings show that non-communicative whole Language instructional approach was the most prominent type of second language acquisition (SLA) instructional approach while for the second language reading instructional approach, the non-interactive reading instructional approach was highly reflected with teacher role primarily inferred as a director. The findings suggest that the instructional approaches reflected in the Malaysian secondary English language reading curriculum is not in alignment with the communicative grounding as an approach to instruction.
\end{abstract}

Keywords: communicative, approach, design, reading curriculum, English language reading, instruction

\section{INTRODUCTION}

Within the Malaysian setting, numerous studies in the field of English language teaching and learning (e.g., Sidek, 2010b-EFL reading attitudes; Sidek, 2012-EFL personality traits; Sidek \& Rahim, 2013; 2015cross-linguistics; Abdullah \& Sidek, 2012-writing feedback; Saad et al., 2016a; 2016b-EFL learning experience; Baharun et al., 2016-Task-based learning; Sidek et al., 2016a-EFL reading fluency; Sidek et al., 2016b-abstract writing in EFL) had been conducted in order to improve the English as a second language (ESL) instructional approach. Connecting the field of second language acquisition (SLA) and language teaching, a teacher's selected instructional approach will reflect a certain theory (e.g., Sidek, 
2010b). The theory grounded in the instructional approach can be determined by certain characteristics. One of the assessing tools for language teaching is by defining the components of language teaching. Edward Anthony (1963) originated the definition of language teaching as a framework of hierarchical components, which entails Approach, Method and Techniques. Using Anthony's definition of language teaching, Richards and Rodgers (2001) constructed a model of Method for language teaching. According to Richards and Rodgers (2001), Method can be defined as comprising three components: Approach, Design and Procedure. The Approach level denotes theory of language and language learning. The Design level can be characterized by elements such as language skills, learning tasks, learner roles and teacher roles. The Procedure level entails elements such as classroom techniques, classroom observation, and interviews with educational stakeholders. Using Richards and Rodgers' (2001) model of Method as a guideline, Sidek (2010a), developed the Method of the teaching of reading.

Sidek's (2010a) method analysis for the teaching of reading also comprises two levels; Approach and Design. Within the framework of Sidek's (2010a) model, Approach comprises the theories of SLA and their corresponding instructional approaches and the theories of second language (L2) reading and their corresponding instructional approaches. The Design level comprises elements such as reading tasks, learner roles and teacher roles. However, the study reported in this paper only analyzed the selected curriculum in terms of SLA instructional approaches, L2 the method of the teaching of reading and teacher role. The curriculum examined in the sample study was the Malaysian Form Five English language reading curriculum, which was extracted from the Form Five English Language curriculum documents. The purpose to identify the instructional approaches and teacher role was to examine the alignment of the Form Five English Language Curriculum with the communicative theoretical underpinning, which is the selected theoretical framework for the curriculum.

\section{COMMUNICATIVE LANGUAGE TEACHING}

Use as many sections and subsections as you need (e.g. Introduction, Methodology, Results, Conclusions, etc.) and end the paper with the list of references. In contrast to a direct approach or traditional approach, the communicative approach is considered an indirect approach to L2 instruction (Celce-Murcia, Dornyei, \& Terrell, 1997) and is also viewed as a learner-centered approach (Nunan, 1988). Current communicative approaches to L2 instruction are the products of CLT methodologies, which emerged in the 1970s and spread in the 1980s. CLT as a general approach to L2 instruction is based on the theory of language as communication with the goal of developing communicative competence; grammatical competence, sociolinguistic competence, discourse competence (Canale \& Swain, 1980), and strategic competence (Canale, 1983). This is in line with socio-cultural theory (SCT), which views language as a tool in a socially mediated process (Vygotsky, 1978) and as a central tool for the development of thought processes or the crucial means of mediation for one's cognition.

The CLT approach is based primarily on the principle of providing students with meaningful communicative language activities in which the language activities are suitable to learners' needs and thus promote the development of communicative competence. Such language activities entail communicative processes, which learners engage in. Activities that encourage students to ask for more information, seek clarification, and to use linguistic and non-linguistic resources to make meaning are considered communicative activities (Savignon, 1991). Every aspect of the CLT approach is done with communicative intent (Larsen-Freeman, as cited in Rao, 2002). Within the CLT approach, learners often play the role as a negotiator whereby they negotiate meaning in small groups or as a whole class in order to fulfill the assigned tasks; this ideally creates an interdependent social relationship in which learners affect others' learning and their learning is also affected by others in their learning context (Breen \&Candlin, 1980).

\section{AUDIO-LINGUAL METHOD}

The audio-lingual instructional approach is related to the use of oral-aural skills as the primary vehicle in L2 instruction. This instructional approach was widely practised before the emergence of communicative approaches. Although the Malaysian secondary English as a Second Language (ESL) curriculum is claimed to be based on a communicative approach (from 1975 to present), the curriculum also contains characteristics of audio-lingual instructional approaches. The learning theory is heavily drawn from behaviorism (Castagnaro, 2006). This method is based on structural linguistics in which language and speech are considered synonymous (Saville-Troike, 1973). The goal of language learning in this approach is to acquire the structural organization of the target language as it is used by native speakers. In terms of learning tasks, dialogue, drills, and pattern practice are the common language activities (Oebel, 2001). Teachers are viewed as directors who direct students for skill training to produce correct language utterances in line with the behaviorist learning theory. Behaviorist theories postulate that in order to acquire a language one needs to acquire the forms of the language, which are best taught using reinforcement or 
repetitive practices. Reinforcement of responses to particular stimuli is believed to form the desired learning behaviors. Typical language instruction within the behaviorist theory often involves activities such as rotememorization and drills.

\section{COMMUNICATIVE WHOLE CLASS INSTRUCTIONAL APPROACH}

The Communicative Whole Language instructional approach was developed based on the theory of language as communication or social activity, which can be connected to the major SLA theories such as the socio-cultural and socio-cognitive theories. Learners use their experiences to construct meaning from the text. The primary goal is to teach reading and writing skills by using real communication. Learners are viewed as collaborators with their peers and evaluators of their own learning (Goodman, 1989; Sidek, 2012a). In second language (L2) reading instruction, learning tasks assimilate the use of language in real world such as reading activities for comprehension and real purpose that are related to learners' real life experiences (Moorman, Blanton, \& McLaughlin, 1994). The tasks require higher order thinking and linguistic skills such as arguing on the author's viewpoint in a discussion and provide reasoning, discussing cause and effects of events in an expository text and so forth. Reading and writing are integrated in meaningful and functional activities (e.g., Freeman \& Freeman, 1992) such as writing in response to a reading activity. In contrast, Non-Communicative Whole Language instructional approach is designed along the cognitive information processing theory such as reflected by the initiation-response-evaluation instructional pattern of which the teacher plays a role as director rather than a catalyst (e.g., Nagaraju, Madhavaih\& Peter, 2013).

\section{GRAMMAR TRANSLATION METHOD}

The Grammar Translation approach (GT) involves using reading to explain grammar rules and to learn vocabulary (Wang, 2009). GT was originally used to teach literature to L1 speakers (Chen, 2008). In English as a foreign language (EFL) classroom, GT involves the teacher translating the English text, explaining grammar rules, and focusing on vocabulary (Wang, 2009). Learners are often instructed to read the text and their attention is commonly directed to learning grammar rules and vocabulary (e.g., Griffiths \& Parr, 2001), which results in the directive pattern of teacher role. This form-focused instructional approach for reading has been criticized for centering on the teacher, involving substantial drilling, and disregarding the role of meaning (Ochs \&Schieffelin, 1995).

\section{THEORETICAL FRAMEWORK}

There is an ongoing phenomenon amongst students in non-native English speaking countries such as China, Norway, Thailand, France (Korean Ministry of Education, 1997 as cited in Butler, 2005) and Japan (Hashimoto, 2006), especially those at the university level who frequently faced with difficulty when processing academic texts in English (e.g., David \& Govindasamy, 2006; Faizah, Zalizan, \& Norzaini, 2002; Inderjit, 2014; Nambiar, 2005; Pandian, 2000; Sidek, 2011). There are many reasons that may contribute to such a phenomenon and one of the possible causes is the misalignment issue in the English language reading curriculum at the school level (e.g., Sidek \& Ab. Rahim, 2014; Sidek, 2010a; 2012a; 2012b).

A coherent curriculum is the one that is properly aligned at all levels and as such a misaligned curriculum may work adversely towards the achievement of the curriculum goals (e.g., Biggs \& Tang, 2003; 2007). Prior to this pioneering study, the Malaysian English language Communicational Syllabus had been examined by Richards (1985). In these studies the speaking tasks in the Malaysian English Language Curriculum introduced in 1975 and 1981 were analyzed. The results show that the speaking tasks in these curricular corresponded with the Task-Based Instruction theoretical underpinning. In the contrary, the present study examined the reading tasks in the Form Five English language reading curriculum, which was extracted from the curriculum documents related to the Form Five English Language Curriculum developed in 2003, with regards to its alignment at the Approach and Design levels with communicative theoretical underpinning in terms of SLA instructional approach, L2 instructional approach and teacher role.

\section{METHODOLOGY}

The purpose of this study was to investigate the alignment of the instructional approaches suggested in the Malaysian Form Five English language reading curriculum by analyzing the reading tasks at the levels of Approach and Design. The following research questions guided the study:

RQ1: What (SLA) instructional approaches are reflected in the Malaysian Form Five English language reading curriculum?

RQ2: What L2 reading instructional approaches are reflected in the Malaysian Form Five English language reading curriculum? 
RQ3: What types of teacher roles can be inferred from the Malaysian Form Five English language reading curriculum?

\subsection{Research Setting}

The research context for the current study was the Malaysian Form Five English language secondary reading curriculum. The Form Five is equivalent to the sophomore year in American highs schools, nonetheless the senior year in the Malaysian secondary school educational system. It is the last grade at the secondary school level prior to students assuming their schooling at a post-secondary institution that matches to their results in the Malaysian national norm-referenced test or known as the Malaysian Certificate of Examination.

\subsection{Instruments}

The instruments used in the study were the Form Five English language textbook and the Form Five English Language Curriculum Specifications document. The Form Five English language textbook is a mandated textbook by the Malaysian Ministry of Education (MOE). English language teachers are required to incorporate the use of the textbook in their English language instruction. Nonetheless, they are allowed to use additional materials including commercial materials, which are relevant. The organization and the content of the selected Form Five ESL textbook related to ESL reading were reviewed because these elements may reflect the instructional approach proposed in the textbook.The Form Five English Language Specifications document comprises learning outcomes and the specifications on the skills to achieve the stipulated learning outcomes

\section{DATA COLLECTION}

The data collection was conducted via the document review method of the selected curriculum documents for the present study. Statements in the selected curriculum documents that are related to reading were extracted. These reading-related statements were inferred as reading tasks. The reading tasks from the selected documents were combined and labeled as the Form Five English language reading curriculum. The validity indexes of statements inferred as reading tasks in the Form Five English Language Curriculum Specifications document and in the Form Five English language textbook are 0.88 and 0.94 respectively.

\section{DATA ANALYSIS}

Manifest content analysis was used in analyzing the data for the present study. The coding for reading tasks for each variable examined in this study is as follows:

Second Language Acquisition (SLA) Instructional Approaches:The Structural-Based instructional method was inferred in reading tasks such as the following:

- Listening to, repeating and knowing the difference between consonants, vowels, dipthongs, consonant clusters, homophones, homographs, and words borrowed from other languages in a dictated text;

- Using the dictionary to find the meanings of words

Reading tasks inferred as reflecting the Non-Communicative Whole Language instructional approach were such as:

- Process information by skimming and scanning for specific information and ideas in a text;

- Systematically making tables to compare the information in a text;

- Process information by extracting main ideas and details in a text;

Reading tasks inferred as reflecting Communicative Language Teaching were similar to the following:

- Get students to read and tell the view of different people who saw the incident as reported in the newspaper

- Filling in a form or writing a short note stating precisely what is required (based on information in a reading text)

- Encourage student to give logical reasons based on a text read

- Reading topics of current interest and exchanging ideas

Second Language Reading Instructional Approaches: Reading tasks inferred as reflective of the StructuralBased Reading instructional approach are such as: 
- Listening to, repeating and knowing the difference between consonants, vowels, dipthongs, consonant clusters, homophones, homographs, and words borrowed from other languages in a dictated text

- Pronouncing words clearly and correctly and asking questions and making statements with the correct intonation, word stress and sentence rhythm

Examples of statements that were inferred as reflective of the Non-Interactive Reading instructional approach are:

- Relating personal experiences

- Reading silently a variety of materials in print and from the internet

- Process information by skimming and scanning for specific information and ideas in a text

Examples of statements that were inferred as reflective of the Interactive Reading instructional approach are:

- Reading topics of current interest and exchanging ideas

- Giving opinions on articles read

Types of Teacher Roles:Examples of reading tasks categorized as teacher as a director were:

- Using the dictionary to find the meanings of words

- Read an excerpt and underline all verbs in Simple Present Tense

- Read an excerpt and change all verbs into Simple Past Tense

- Read a poem and changed underlined verbs into the Past Tense form

Examples of reading tasks categorized as teacher as a catalyst were:

- Reading topics of current interest and exchanging ideas

- Giving opinions on articles read

\section{FINDINGS AND DISCUSSION}

The findings are presented according to the variables examined in the research questions.

\subsection{SLA Instructional Approach}

The findings for SLA instructional approaches for the selected documents are presented in Tables 1, 2 and 3.

Table 1: Analysis of SLA Instructional Approaches in English Language Curriculum Specifications Document

\begin{tabular}{|l|l|}
\hline Instructional Approaches & Percentage (\%) \\
\hline Non-Communicative Whole Language & 64.7 \\
\hline Communicative Whole Language & 30.6 \\
\hline Structural-Based & 4.7 \\
\hline
\end{tabular}

Table 2: Analysis of SLA Instructional Approaches in English Language Textbook

\begin{tabular}{|l|l|}
\hline Instructional Approaches & Percentage (\%) \\
\hline Non-Communicative Whole Language & 77.0 \\
\hline Communicative Whole Language & 16.2 \\
\hline Structural-Based & 6.8 \\
\hline
\end{tabular}

Table 2 shows that in the Form Five English Language Curriculum Specifications document, the NonCommunicative Whole Language instructional approach is significantly reflected (64.7\%). On the contrary, only $30.6 \%$ of the reading tasks in the Form Five English Language Curriculum Specifications reflects the Communicative Language Teaching instructional approach with $4.7 \%$ of the reading task categorized as under the Structural-Based instructional approach. In Table 3, a similar pattern of the dominance of NonCommunicative Whole Language instructional approach (77\%) was found in the Form Five English language textbook. Unlike the finding for the reading tasks in the Form Five English Language Curriculum Specifications, the Communicative Language Teaching instructional approach is insignificantly reflected $(6.8 \%)$ in the Form Five English language textbook with Structural-Based being more domineering (16.2\%). The overall analysis of SLA instructional approaches is presented in Table 3. 
Table 3: Overall Analysis of SLA Instructional Approaches in English Language Curriculum Specifications Document and English Language Textbook

\begin{tabular}{|l|l|}
\hline Instructional Approaches & Percentage (\%) \\
\hline Non-Communicative Whole Language & 75.7 \\
\hline Communicative Whole Language & 14.1 \\
\hline Structural-Based & 12.7 \\
\hline
\end{tabular}

Table 3 shows that, in general, the Non-Communicative Whole Language instructional approach is highly reflected in the Malaysian Form Five English language reading curriculum (75.7\%). The Communicative Language Teaching instructional approach is reflected for only $14.1 \%$ while the Structural-Based instructional approach is reflected at a slightly lower percentage (12.7) than the Communicative Language Teaching instructional approach.

\subsection{L2 Reading Instructional Approach}

The findings for L2 reading instructional approaches are presented in Tables 5, 6 and 7 .

Table 5: Analysis of L2 Reading Instructional Approaches in English Language Curriculum Specifications Document

\begin{tabular}{|l|l|}
\hline Instructional Approaches & Percentage (\%) \\
\hline Grammar Translation & 15.3 \\
\hline Non-Interactive Reading Instructional Approach & 60.0 \\
\hline Interactive Reading Instructional Approach & 24.7 \\
\hline
\end{tabular}

Table 6: Analysis of L2 Reading Instructional Approaches in English Language Textbook

\begin{tabular}{|l|l|}
\hline Instructional Approaches & Percentage (\%) \\
\hline Grammar Translation & 25.1 \\
\hline Non-Interactive Reading Instructional Approach & 65.4 \\
\hline Interactive Reading Instructional Approach & 9.4 \\
\hline
\end{tabular}

Table 5 exhibits that in the Form Five English Language Curriculum Specifications document, the noninteractive reading instructional approach is most prominently reflected $(60 \%)$. However, the interactive reading instructional approach is merely reflected for $24.7 \%$ with Grammar Translation method being reflected for $15.3 \%$.Table 6 shows a similar finding on the significance of the non-interactive reading instructional approach in the Form Five English language textbook carrying $64.5 \%$. The interactive L2 reading instructional approach is the least reflected (9.4\%) in comparison to Grammar Translation method that carries $21.5 \%$ of the reading tasks.

Table 7: Overall Analysis of L2 Reading Instructional Approaches in English Language Curriculum Specifications Document and English Language Textbook

\begin{tabular}{|l|l|}
\hline Instructional Approaches & Percentage (\%) \\
\hline Grammar Translation & 22.1 \\
\hline Non-Interactive Reading Instructional Approach & 63.8 \\
\hline Interactive Reading Instructional Approach & 14.1 \\
\hline
\end{tabular}

Table 7 shows that, the non-interactive reading instructional approach is most significantly reflected in the Malaysian Form Five English language reading curriculum (63.8\%). The interactive L2 reading instructional approach is reflected for only $14.1 \%$ while the Grammar Translation method is reflected at a higher percentage (22.1\%) than the interactive L2 reading instructional approach.

\subsection{Teacher Roles}

The findings for learner role are presented in Tables 8, 9 and 10.

Table 8: Analysis of Learner Roles in English Language Curriculum Specifications Document

\begin{tabular}{|l|l|}
\hline Types of Teacher Roles & Percentage (\%) \\
\hline Director & 82.4 \\
\hline Catalyst & 17.6 \\
\hline
\end{tabular}


IJASOS- International E-Journal of Advances in Social Sciences, Vol. III, Issue 8, August 2017

Table 9: Analysis of Learner Roles in English Language Textbook

\begin{tabular}{|l|l|}
\hline Types of Teacher Roles & Percentage (\%) \\
\hline Director & 88.0 \\
\hline Catalyst & 12.0 \\
\hline
\end{tabular}

Table 10: Overall Analysis of Teacher Role in English Language Curriculum Specifications Document and English Language Textbook

\begin{tabular}{|l|l|}
\hline Types of Teacher Roles & Percentage (\%) \\
\hline Director & 89.1 \\
\hline Catalyst & 10.9 \\
\hline
\end{tabular}

Table 8 displays that reading tasks in the Form Five English Language Curriculum Specifications document highly reflect teacher role as a director (82.4\%). Only $17.6 \%$ of the tasks reflect teacher role as a catalyst. Similarly, in Table 9, $88 \%$ of the reading tasks in the Form Five English language textbook reflect teacher role as a director. Only $12 \%$ of the reading tasks reflects teacher role as a catalyst. Combining the findings of both documents as shown in Table 10, in general, $89.1 \%$ of the reading tasks in the Malaysian English language reading curriculum reflect the teacher role as a director while only $10.9 \%$ of the reading tasks reflect the teacher role as a catalyst.

As a whole, the Malaysian Form Five English Language Secondary Curriculum is labeled as a communicative curriculum (Ministry of Education, Malaysia [MOE]). As such, this label suggests that the Malaysian Form Five English language secondary school reading curriculum should also reflect instructional approaches that are related to the communicative theoretical underpinnings. However, the findings in the current study provide adverse evidence that the Malaysian Form Five English Language secondary reading curriculum is not in alignment with its communicative label. The findings on SLA instructional approaches and $L 2$ reading instructional approaches in this study indicate that the English language secondary reading curriculum was primarily developed based on the non-communicative related theories of SLA such as the cognitive theory and structural linguistics. In order for the curriculum to reflect communicative theoretical underpinnings, SLA instructional approaches and L2 reading instructional approaches reflected in the curriculum should be the ones connected to communicative related theories such as the socio-cognitive and socio-cultural theories embedded in the reading tasks. These findings corroborate with the findings of past studies of similar nature (e.g., Ahmed, Puteh-Behak \& Sidek, 2015; Baharun et al., 2016; Mohammed \& Sidek, 2015; Sidek, 2010a).

The finding on the teacher roles corroborates with the findings of Nambiar (2005) and Ponniah (1993) regarding English language reading instructional procedures within the Malaysian setting, which are more non-communicative in nature (e.g., Sidek, 2013; Sidek, Abdullah \& Rahim, 2013; Sidek \& Abdullah, 2013; Sidek, Abdullah, Rahim \& Mohammed, 2014). Despite communicative features being evidenced by the data on teacher role as a catalyst, such features are way less prominent in comparison to the evidence of noncommunicative features. The misalignment of the instructional approaches and teacher role with regards to communicative grounding might affect the curriculum coherency, which may defeat the achievement of the curriculum intended goals. The English language textbook is developed using the Curriculum Specifications document as guidelines because the Malaysian Ministry of Education mandates such conformant. When the Curriculum Specifications document fails to conform to the selected theoretical underpinning, such condition will affect the approach and design of the content of the textbook. As such, the misalignment continues in the textbook and in classroom implementation.

It is a common practice for teachers to use textbooks as instructional guidelines because textbooks are curriculum materials that represent social artifacts developed by curriculum designers (Putnam \& Borko, 2000; Salomon, 1993). However, whether the secondary school English language teachers within the Malaysian setting are capable of evaluating the extent to which the textbook conforms to the Curriculum Specifications document is an area of question (e.g., Sidek, 2012b; Sidek, 2014). As contended by Williams (1983) who studied EFL teachers' knowledge in evaluating English language textbooks within the Malaysian setting, most EFL teachers are neither trained to interpret a textbook's intentions, nor able to evaluate its content and method. As such, within the Malaysian secondary educational setting, the textbook seems to be commonly used as instructional guidelines that teachers often assume to fully represent the intended instructional approaches as designed in the Curriculum Specification document. In effect, the misalignment in reading tasks between those in the English language textbook and the ones presented in the English Language Curriculum Specifications document may subsequently affect classroom implementation, which in turn may defeat one of the ultimate goals of the English Language Secondary Curriculum. 


\section{CONCLUSION}

Based on the findings of the present study, there is a need for the Malaysian Form Five English language secondary reading curriculum to be revised at the level of Approach and Design. Such revision should involve designing reading tasks that reflect the communicative theoretical underpinning. In order to do this, the revision should also take the role of context into account so as that the reading tasks will reflect teacher role as a catalyst instead of a director. Such revision is imperative to ensure that the approach and design for the teaching of English language reading presented in the curriculum are coherent and explicitly reflective of the intended communicative instructional approach.

\section{REFERENCE LIST}

Abdullah. H \& Sidek, H.M. (2012). L2 writing feedback: Alignment of instructional planning and implementation. Journal of Language Studies, 15, 15-17.

Ahmed, H., Puteh-Behak, F. \& Sidek, H.M. (2015). Examining EFL secondary reading curriculum in Iraqi Kurdistan: A review. Journal of Applied Sciences, 15(3), 377-391.

Baharun, H., Sidek, H.M., Saad N.S.M., Idrus, M.M., Harun, H., Darmi. R, Abdullah, N. \& Ashikin, Z. (2016). The Malaysain secondary school EFL speaking curriculum: A theoretical foundation alignment analysis. International Journal of Advance Social Sciences, 2(6), 465-474.

Biggs. J.\& Tang, C. (2003). Teaching for Quality Learning at University.2nd Edition. McGraw Hill: The Society for Research into Higher Education \& Open University Press.

Biggs. J.\& Tang, C. (2007). Teaching for Quality Learning at University. ${ }^{\text {rd }}$ Edition. McGraw Hill: The Society for Research into Higher Education \& Open University Press.

David, M. K. \&Govindasamy, S. (2006). National identity and globalization in Malaysia. In Tsui, A. B. M., \& J. W. Tollefson (Eds.), Language Policy, Culture, and identity in Asian Contexts, (pp. 55-72). Lawrence Erlbaum: Mahwah, New Jersey.

Edward Anthony (1963). Approach, method, and technique.English Language Teaching, 17(2), 63-67.

Faizah, A.M., Zalizan, M. J., \&Norzaini, A. (2002).Selected Malaysian adult learners' academic reading strategies: A case study.Retrieved from http://www.face. stir.ac.uk/ Majidp61.htm.

Hashimoto, K. 2006. Japan's language policy and the lost decade. In Tsui, A. B. M., \& J. W. Tollefson (Eds.), Language policy, culture, and identity in Asian contexts, (pp. 25-36). Lawrence Erlbaum: Mahwah, New Jersey.

Inderjit, S. (2014). Reading trends and improving reading skills in Malaysia. International Journal of Research in Social Sciences, 3(5), 70-81.

Korean Ministry of Education.(1997). The English education policies in elementary school. Seoul: Ministry of Education. As cited in Butler, Y. G. (2005). Comparative perspectives toward communicative activities among elementary school teachers in South Korea, Japan, and Taiwan.Language Teaching, 9(4), 423446.

Mohammed, A.L. \&Sidek, H.M. (2015). EST reading curriculum and instruction: Alignment analysis. Advances in Language and Literary Studies. 6(1), 120-128.

Nagaraju, C., Madhavaiah, G. \& Peter, S. (2013). Teacher-centred learning and student-centred learning in theEnglish classroom: the teaching methods for realising the dreams of language learners. InternationalJournal of Scientific Research and Reviews (IJSRR), 2(3), 125-131

Nambiar, G. R. (2005). Why don't they read the way they should? Online submission. (ERIC Document Reproduction Service No ED 4903379). Retrieved from http://www.google.com/search?hl=en\&q=radha+nambiar-gopal.

Pandian, A. (2000).A study on readership behaviour among multi-ethnic, multi-lingual Malaysian students. A paper presented at the seventh International Literacy and Education Research Network (LERN) Conference on Learning, RMIT University, Melbourne, 5-9 July 2000. 
Ponniah, K.S. (1993). Improving academic reading ability of EFL students at tertiary level.Unpublished Doctoral Dissertation. University of Malaya, Kuala Lumpur.

Richards, J. C. \& Rodgers, T. S. (2001).Approaches and methods in language teaching. New York: Cambridge University Press.

Richards, J.C. (1985). Language Curriculum Development.Department of English as Second Language.University of Hawaii, Honolulu, USA.

Putnam, R. T., \&Borko, H. (2000). What do new views of knowledge and thinking have to say about research on teacher learning? Educational Researcher, 29(1), 4-15.

Saad, N.S.M., Yamat, Y., Sidek, H.M., Baharun, H. \& Idrus, M.M. (2016a), Acts of Agency in English Language Learning Experience. International E-journal of Advances in Social Sciences, 2(6), 733746.

Saad, N.S.M., Sidek, H.M., Baharun, H. \& Idrus, M.M. \& Yunus. M.Y. (2016b). A Conceptual Framework to Explore the English Language Learning Experiences of International Students in Malaysia. International E-journal of Advances in Social Sciences, 2(6), 453-464.

Salomon, G. (1993). Distributed cognitions: Psychological and educational considerations. Cambridge England: New York NY.

Sidek, H. M. (2010a). An analysis of the EFL secondary reading curriculum in Malaysia: approaches to reading and preparation for higher education. Doctor of Philosophy, University of Pittsburgh.

Sidek, H. M. (2010c). Reading Instruction: Theory and Practice. Nilai: Usim Publisher.

Sidek, H.M. (2011). Methods of EFL secondary reading instruction: Preparation of higher education. International Journal of Humanities and Social Science, 1(3), 181-191.

Sidek, H. M. (2012a). EFL reading instruction: Communicative task-based approach. International Journal of Instruction, 5(2), 109-128.

Sidek, H.M. (2010b). Reading Attitudes a Case Study in Malaysia. Annals of Language Teaching, (pp. 209215), Boca Raton, Florida: Universal-Publishers.

Sidek, H. M. (2012b). EFL textbook analysis: A case study. Language and Literacy Journal, 14(3), 27-45.

Sidek, H.M. (2012c). Reading Attitudes: A Case Study in Malaysia. Annals of Language and Learning: Proceedings of the 2009 International Online Language Conference (IOLC 2009), p.209. Boca Raton: Universal Publisher.

Sidek, H.M. (2012d). EFL Language Learning Personality Traits and Instruction. International Journal of Learning, 18(5), 255-272.

Sidek, H. M. (2013). A Cross-Linguistic Study of Vocabulary Knowledge and Second Language Reading Development. Frontiers of Language and Teaching, 4, 178-185.

Sidek, H. M. (2013). Communicative reading instructional approach: A Curriculum Review. International Journal of Interdisciplinary Educational Studies, 7(1), 9-20.

Sidek, H. M. \& Abdullah, H. (2013). EFL Reading Comprehension and Preparation For Higher Education: A Textbook Analysis. Journal of Teaching and Education, 24(4), 425-435.

Sidek, H. M., Abdullah, H. \& Rahim, H.A. (2013). Reading Curriculum and Instructional Analysis: Preparation for Academic Literacy at Higher Institutions. Journal of Teaching and Education, 2(2), 389-396.

Sidek, H.M., H. Abdullah, H.A. Rahim \& Mohamed, Y. (2014). ESL Reading Instruction: Alignment of Curriculum and Implementation. Procedia-Social and Behavioral Sciences, 118, 442-449.

Sidek, H. M. (2014). English Language Reading Preparation for Higher Education: An Evaluation of the Form Four English Language Textbook and Instructional Design. Journal of Social Science and Humanities (PERTANIKA), 22(2), 539-558.

Sidek, H., \& Rahim, H. (2014). ESL reading instruction: Alignment of curriculum implementation. Paper presented at the 6th International Conference on Education and New Learning Technologies, Barcelona, Spain. 
Sidek, H.M., Saad, N.S.M., Baharun, H. \& Idrus, M.M. (2016a). An Analysis of Rhetorical Moves in Abstract in Conference Prioceedings. International E-journal of Advances in Social Sciences, 2(4), 24-31.

Sidek, H.M., Baharun, H., Saad, N.S.M., \& Idrus, M.M. (2016b). English as a Foreign Language Fluency: A Pilot Study. International E-journal of Advances in Social Sciences, 2(4), 70-79.

Williams, D. (1983). Developing criteria for textbook evaluation. ELT Journal, 37(3), 251-255. 